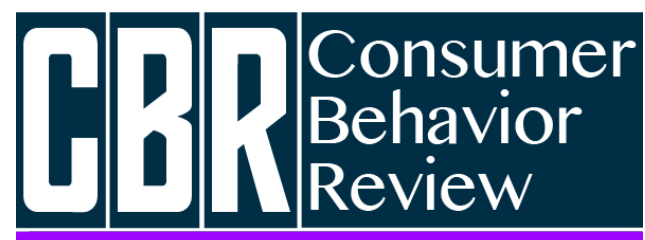

Revista Comportamento do Consumidor

Hamza, K. M., Nogami, V. K. C. \& Andrade, J. (2017). Reward and punishment from consumers towards ethical and corrupt companies: A study on price promotion and purchase intention. Consumer Behavior Review, 1(1) 38-44.

ISSN: 2526-7884

Editor: Prof. Dr. Marconi Freitas da Costa Email da revista: cbr@ufpe.br

Avaliação: Double blind review

Recebido: 21 de dezembro de 2016

Aceito: 7 de abril de 2017

\title{
REWARD AND PUNISHMENT FROM CONSUMERS TOWARDS ETHICAL AND CORRUPT COMPANIES: A STUDY ON PRICE PROMOTION AND PURCHASE INTENTION
}

\author{
Kavita Miadaira Hamza \\ Vitor Koki da Costa Nogami \\ Josmar Andrade
}

Kavita Miadaira Hamza é Professora de Marketing da Faculdade de Economia, Administração e Contabilidade da Universidade de São Paulo - USP. Email: kavita@usp.br. Vitor Koki da Costa Nogami é Professor de Marketing da Fundação Instituto de Administração - FIA. E-mail: vitornogami@gmail.com._Josmar Andrade é Professor de Marketing da Escola de Artes, Ciências e Humanidades da Universidade de São Paulo - EACH-USP. E-mail: josmar@usp.br. Esta pesquisa teve o apoio da Coordenação de Aperfeiçoamento de Pessoal de Nível Superior - CAPES. Os autores agracedecem aos avaliadores pelos comentários para melhoria do artigo.

\begin{abstract}
Although many studies investigate if consumers punish or reward un/ethical products, there were not find researches specific on consumer behavior towards ethical and corrupt companies, so it is an important gap, which we intend to cover. The purpose of this study was to verify if price promotion and company profile (ethical or corrupt) influence purchase intentions. It was used an experiment using 2 (price promotion: discount vs. no discount) vs. 3 (company profile: corrupt vs. NCNE vs. ethical) groups, with a sample of 246 cases between subjects. Our findings show consumers do not value the ethical behavior of companies, but penalize corrupt behavior. The price promotion stimulus was also not effective, which means that price promotion does not affect the willingness to pay. The results suggest that companies should behave ethically, if not by the reward they could get for it, at least for the punishment consumers are willing to give them.

Keywords: Business Ethics; Ethical Consumer; Corruption.
\end{abstract}

Esta obra está licenciado com uma Licença Creative Commons Atribuição 4.0 Internacional.

\section{INTRODUCTION}

Ethical consumption derives from the consumerism discussion (Carey, Shaw \& Shiu,
2008) and covers different issues like business ethics, fair trade goods, organic products, animal welfare and social concerns (Wheale \& 
Hinton, 2007; Trudel \& Cotte, 2009). The importance of these issues varies among consumers, being environmental issues most considered during purchase decisions (Wheale $\&$ Hinton, 2007).

Some consumers, especially those who consider social corporate responsibility important, are willing to punish companies with a questionable corporate behavior (Miller \& Sturdivant, 1977). It's also increasing the number of consumers concerned about and with a positive attitude towards ethical products (White, MacDonnell \& Ellard, 2012; Jägel, Keeling, Reppel \& Gruber, 2012). Besides that, the attitude/behavior gap is still strong, as consumers are more aware of ethical issues, but they are struggling to modify their choices, rarely rewarding these kinds of goods (Young, Hwang, McDonald \& Oates 2010; Carrington, Neville \& Whitwell, 2010; Uusitalo \& Oksanen, 2004). This same gap was found on sustainable products by Gleim, Smith, Andrews and Cronin (2013), which discuss similar difficulties of consumer behavior towards these kind of products.

Many studies investigate if consumers punish or reward un/ethical products both in a general way (Trudel \& Cotte, 2009; Carrington et al., 2010; Moosmayer, 2012; Papaoikonomou, 2013) and in specific issues such as fair trade (Uusitalo \& Oksanen, 2004; White et al., 2012), clothing (Jägel et al., 2012), food (Miller \& Sturdivant, 1977). However, there were not find specific researches about the influence of price promotion on consumer behavior towards ethical and corrupt companies. As many studies discuss the effect of price promotions on attracting shoppers (Mulhern \& Padgett, 1995; Van Heerde, 2005), this is an important gap, which this paper intend to cover. The purpose of this study is to verify if price promotion and company profile (ethical or corrupt) influence purchase intentions.

In the next two sessions, it will be discussed previous research on corporate social responsibility and the ethical consumer. In addition, is presented the method design of the present study, followed by results found, discussion, and conclusions.

\section{CORPORATE SOCIAL RESPONSIBILITY (CSR)}

Social responsibility has become an important corporate goal. It is no longer enough that shareholders' goals are attained; corporations are also increasingly being evaluated based on how they meet society's ethical and moral values (Uusitalo \& Oksanen, 2004).

Although some say there is a recent shift from the self-interested companies to an era of corporate social responsibility (Trudel \& Cotte, 2009), there are evidences referring companies concerned about society for a long time, and the first ones found are from the 1930s and 1940s (Carroll, 1999). However, the proliferation of this issue occurred in the 1970s, when its definitions became more specific, considering four main categories: economic, legal, ethical and philanthropic (Carroll, 1999).

Meanwhile, in the 1960s, a new consumer movement arose: the consumerism. Its main pressure was against the rising prices of goods, but rapidly other issues were discussed too, all of them as a result of the exploitative system (Herrmann, 1970).

In the 1990s other concepts related to CSR took place, like stakeholder theory, business ethics and corporate citizenship (Carroll, 1999). Also, sustainability is related to CSR and has its concept development close to CSR discussions. These concepts are very tied to each other, and frequently one refers to the others. Also in this decade the term 'ethical consumers' replaced the 'green consumers', as that was seen as the evolution of the latest one (Papaoikonomou, 2013).

When relating to the ethical consumers, the next topic discussed, studies show that consumers are more sensitive to negative CSR than to positive, punishing unethical companies by stopping and asking others to stop buying products from these companies, and rewarding ethical companies with their willingness to pay (WTP) higher prices for the products (Palihawadana, Oghazi \& Liu, 2016).

\section{THE ETHICAL CONSUMER}

The ethical consumer ideal implies that individual consumers can have a significant role, through their daily purchasing decisions, in promoting ethical corporate practices (Uusitalo \& Oksanen, 2004). 
In general, there are two groups of ethical consumers. The first one is the ethical consumers who seek for ethical products, and valorize more environmental issues than other kind of issues, like human rights and animal welfare. The other group is the 'non-activist' or 'subjectivist' ethical consumers, who often claim they prefer ethical goods, but some factors avoid them to choose these products more often, like strong brands, lack of information on the ethical issues and ethical/price trade-off (Wheale \& Hinton, 2007), among others. Studies with ethical products, such as Fair Trade labelled ones, show that sales increase during periods of price promotions (Andorfer \& Liebe, 2015). Considering these previous studies, we formulated the first hypotheses, as follow. The "nor corrupt neither ethical company" is from this point on called NCNE.

H1: The purchase intention of a product from a corrupt company (a), a NCNE (b), an ethical company (c) is greater when a price promotion is offered.

It is important to note that purchasing and consuming ethical products require a lot of effort on information acquisition and decision making. Consumers may find difficulties regard to consider several ethical aspects simultaneously (Uusitalo \& Oksanen, 2004). Even idealistic ethical consumers strive to be ethical in all decisions, showing some inconsistencies with their ethical self (Papaoikonomou, 2013).

It is hard to consumers to make decisions only considering ethical issues in their buying process. For example, a study conducted by Jägel et al. (2012) on ethical clothing shows that consumers who buy ethical clothing often base their choice not solely on product attributes (such as price, quality, style, etc.) or ethical attributes, but on a combination of both.

Both attributes and personal values are considered as drivers of consumption of ethical products. These values vary from an ethical obligation (support the environment, avoid exploitation, promote better living conditions and so on) to more individual benefits, such as 'look good', 'stay within budget' and 'feel of wearing' (Jägel et al., 2012).

Another important aspect on the ethical consumer is whether he is willing to pay more for ethical products (reward) or to boycott unethical products (punish). Although some studies discuss the attitude/behavior gap (Young et al., 2010; Carrington et al., 2010; Uusitalo \& Oksanen, 2004), others researches demonstrate that consumers are rewarding ethical companies (Clark et al., 2017) and/or punishing the unethical ones (Ferreira \& Ribeiro, 2016). But the punishment behavior seems to be stronger than the reward one, as rewarding good corporate is usually more expensive than punishing the bad ones (Moosmayer, 2012). Furthermore, negative aspects of unethical behavior have a greater impact on willingness to pay (WTP) than the positive effects of ethical behavior (Trudel \& Cotte, 2009).Considering these previous studies, we formulated hypotheses 2 and 3 , as follow.

H2: The purchase intention of a product from an ethical company is greater than the NCNE(a), the purchase intention of a product from an ethical company is greater than the corrupt company (b), and the purchase intention of a product from a NCNE is greater than the corrupt company(c), in the scenario with price promotion.

H3: The purchase intention of a product from an ethical company is greater than the NCNE(a), the purchase intention of a product from an ethical company is greater than the corrupt company (b), and the purchase intention of a product from a NCNEis greater than the corrupt company (c), in the scenario without price promotion.

\section{METHOD DESIGN}

The experiment was designed using 2 (price promotion: discount vs. no discount) vs. 3 (company profile: corrupt vs. NCNE vs. ethical) groups. The purpose was to identify whether the consumer is sensitive to a price promotion (20\% discount), considering the company profile regarding its image. The dependent variable was the purchase intention (Fishbein \& Azjen, 1977), and the product announced was a smartphone. The composition of this construct was structured with 5 items about: purchase probability, purchase suggestions, intention to buy, recommendation to other people and gifting someone. The 5 items were measured on 
a 1-10point measurement, and was obtained a Cronbach's Alpha of 0.88. The recommendations that respondents received were:

[The BETA Company manufactures smartphones recognized as the best in the market, but is also more expensive than other smartphones brands. PRICE PROMOTION There is a discount that reduced the price of these smartphones by $20 \%$ and you are planning to buy one (vs. Even tough, you are planning to buy one). COMPANY PROFILE - This company was accused of corruption by bribing government people to have some benefits in return. The bribery was confirmed, and the case has received extensive media attention (vs. This company is renowned for being extremely ethical in the business management. It has won several awards and the media always point this honor and how this company is ethical). (vs. For NCNE no further information was given].

Data was collected by a relationship network of undergraduate students of the Marketing Course in one of the largest universities in Brazil. Each student received about 10 questionnaires and was responsible for applying them with people that do not study marketing. This choice was made to the opinions wouldn't have any bias towards its issue. The total sample consisted of 246 cases between subjects (Tabachnick \& Fidell, 2007). All questionnaires with missing values were removed from the sample. To analyze the results we used the GLM - General Linear Model (Hair, 2006).

\section{RESULTS}

The results indicated that the consumer is not sensitive to price promotional appeal. This happens for companies considered corrupt, NCNE and ethical ones. In other words, the hypotheses H1a, H1b and H1c were not confirmed. Based on this information, companies which have the image undermined by corruption and consider that any price promotion can mitigate this scenario are committing management mistakes. On the other hand, analyzing the stimulus in NCNE and ethical companies, also no significant differences was found. Figure 1 illustrates the results of the six scenarios studied.

Figure 1

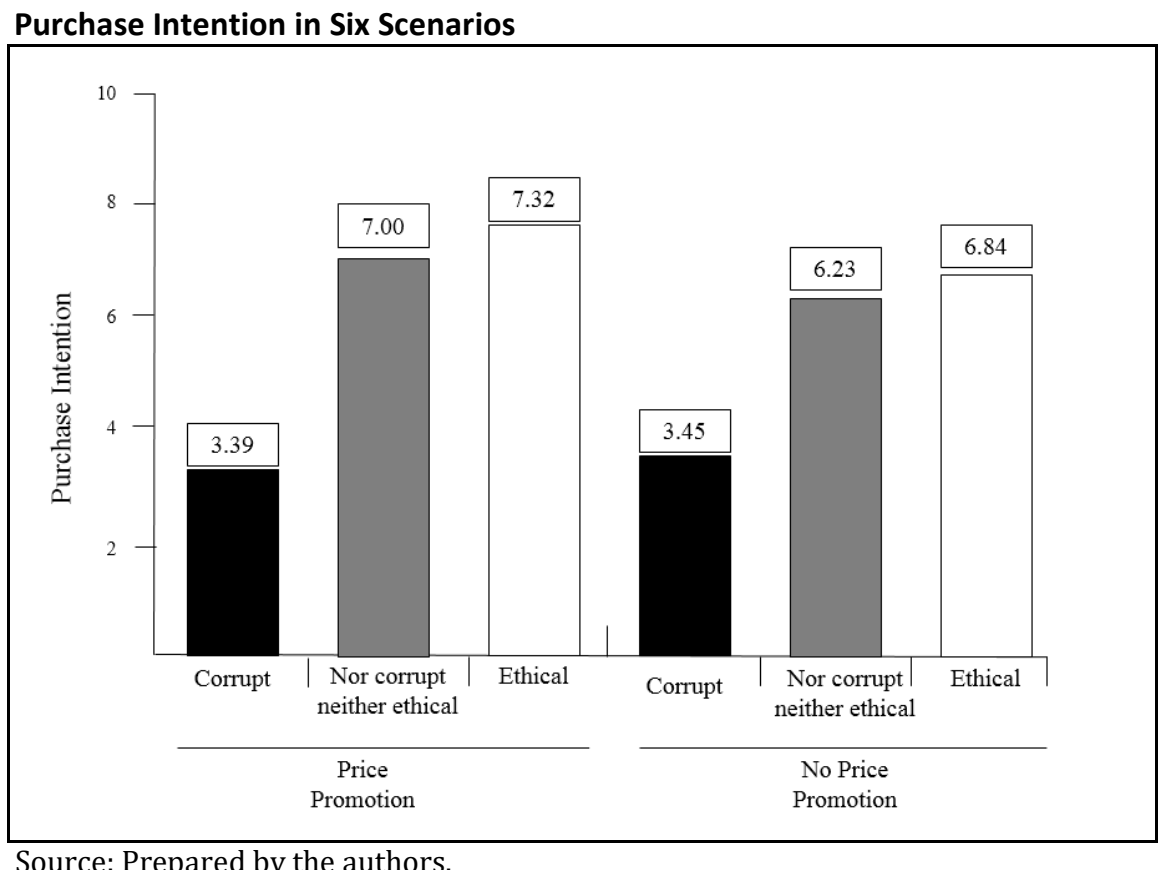

As pointed out in Table 1, the difference in purchase intention of consumers between ethical company and the NCNE was not significant, not confirming $\mathrm{H} 2 \mathrm{a}$ and $\mathrm{H} 3 \mathrm{a}$. This indicates the consumer does not reward the company that has a good reputation. We can 
analyze this information from two perspectives. First, the image of the company (ethical or NCNE) does not influence the smartphone purchase intention. Second, consumers do not consider that the company with an ethical image should be rewarded.

Table 1

Mean Difference in Six Scenarios and Hypotheses Verification

\begin{tabular}{|c|c|c|c|c|c|c|c|c|}
\hline $\begin{array}{l}\text { Purchase } \\
\text { Situation }\end{array}$ & Interaction & $\mathrm{MD}$ & $\begin{array}{l}\text { Purchase } \\
\text { Situation }\end{array}$ & Interaction & $\mathrm{MD}$ & $\begin{array}{l}\text { Purchase } \\
\text { Situation }\end{array}$ & Interaction & $\mathrm{MD}$ \\
\hline $\begin{array}{c}\text { Price } \\
\text { Promotion } \\
\text { and Corrupt } \\
(\mathrm{M}=3.39) \\
(\mathrm{N}=30)\end{array}$ & $\begin{array}{l}\text { No Price Promotion } \mathrm{x} \text { Corrupt } \\
\text { Price Promotion } \mathrm{x} \text { NCNE } \\
\text { No Price Promotion } \mathrm{x} \text { NCNE } \\
\text { Price Promotion } \mathrm{x} \text { Ethical } \\
\text { No Price Promotion } \mathrm{x} \text { Ethical }\end{array}$ & \begin{tabular}{|c|}
0.10 \\
$-3.44 *$ \\
$-2.84 *$ \\
$-3.97 *$ \\
$-3.23 *$
\end{tabular} & $\begin{array}{c}\text { Price } \\
\text { Promotion } \\
\text { and NCNE } \\
(\mathrm{M}= \\
7.00)(\mathrm{N} \\
=48)\end{array}$ & $\begin{array}{l}\text { Price Promotion x Corrupt } \\
\text { No Price Promotion x Corrupt } \\
\text { No Price Promotion x NCNE } \\
\text { Price Promotion x Ethical } \\
\text { No Price Promotion x Ethical }\end{array}$ & $\begin{array}{c}3.44 * \\
3.55^{*} \\
0.60 \\
-0.53 \\
-0.21\end{array}$ & $\begin{array}{c}\text { Price } \\
\text { Promotion } \\
\text { and Ethical } \\
(\mathrm{M}=7.32) \\
(\mathrm{N}=35)\end{array}$ & $\begin{array}{l}\text { Price Promotion x Corrupt } \\
\text { No Price Promotion x Corrupt } \\
\text { Price Promotion x NCNE } \\
\text { No Price Promotion x NCNE } \\
\text { No Price Promotion x Ethical }\end{array}$ & $\begin{array}{l}3.97^{*} \\
4.08^{*} \\
0.53 \\
1.13 \\
0.74\end{array}$ \\
\hline $\begin{array}{l}\text { No Price } \\
\text { Promotion } \\
\text { and Corrupt } \\
(\mathrm{M}=3.45) \\
(\mathrm{N}=49)\end{array}$ & \begin{tabular}{|l|} 
Price Promotion $\mathrm{x}$ Corrupt \\
Price Promotion $\mathrm{x}$ NCNE \\
No Price Promotion $\mathrm{x}$ NCNE \\
Price Promotion $\mathrm{x}$ Ethical \\
No Price Promotion $\mathrm{x}$ Ethical \\
\end{tabular} & \begin{tabular}{|c|}
0.10 \\
$-3.55 *$ \\
$-2.95 *$ \\
$-4.08 *$ \\
$-3.34 *$
\end{tabular} & $\begin{array}{l}\text { No Price } \\
\text { Promotion } \\
\text { and NCNE } \\
(\mathrm{M}= \\
6.23) \quad(\mathrm{N} \\
=46)\end{array}$ & $\begin{array}{l}\text { Price Promotion x Corrupt } \\
\text { No Price Promotion x Corrupt } \\
\text { Price Promotion x NCNE } \\
\text { Price Promotion x Ethical } \\
\text { No Price Promotion x Ethical }\end{array}$ & $\begin{array}{c}2.84 * \\
2.94 * \\
-0.60 \\
-1.13 \\
-0.39 \\
\end{array}$ & \begin{tabular}{|c|} 
No Price \\
Promotion \\
and Ethical \\
$(\mathrm{M}=6,84)$ \\
$(\mathrm{N}=38)$ \\
\end{tabular} & \begin{tabular}{|l|} 
Price Promotion x Corrupt \\
No Price Promotion x Corrupt \\
Price Promotion x NCNE \\
No Price Promotion x NCNE \\
Price Promotion x Ethical \\
\end{tabular} & $\begin{array}{l}3.23^{*} \\
3.34^{*} \\
-0.21 \\
0.39 \\
-0.74\end{array}$ \\
\hline \multicolumn{3}{|c|}{ H1a: Not confirmed } & \multicolumn{3}{|c|}{ H2a: Not confirmed } & \multicolumn{3}{|c|}{ H3a: Not confirmed } \\
\hline \multicolumn{3}{|c|}{ H1b: Not confirmed } & \multicolumn{3}{|c|}{ H2b: Confirmed } & \multicolumn{3}{|c|}{ H3b: Confirmed } \\
\hline \multicolumn{3}{|c|}{ H1c: Not confirmed } & \multicolumn{3}{|c|}{ H2c: Confirmed } & \multicolumn{3}{|c|}{ H3c: Confirmed } \\
\hline
\end{tabular}

M: Mean; N: Sample; MD: Mean Diference; NCNE: Nor corrupt neither ethical. * 0.05

Source: Prepared by the authors

As to comparingto the reputation of the corrupt company these results changes, since significant differences were found. The mean of purchase intention of ethical companies and NCNEare statistically greater than the corrupt companies, as shown in Table 1. Although consumers are not sensitive to ethical corporate image ( $\mathrm{H} 2 \mathrm{a}$ and $\mathrm{H} 3 \mathrm{a}$ ) they are sensitive to the corrupt image of the companies, confirming H2b, H2c, H3b and H3c. That happens both on the scenario with and without price promotion, and in this case the price promotion stimulus was also not effective.

We can point that if the consumer does not value the ethical behavior of companies, on the other hand it penalizes corrupt behavior. As the research results point that ethics image is not valued by consumers, the image is better recognized compared with companies that have a bad reputation in the market. Once there are still bad management practices such as corruption, slave labor, tax evasion, environmental degradation, illegal extraction of resources, illegal animal testing among other prohibited actions, the research shows that this behavior is not well regarded by consumers.

\section{DISCUSSION AND CONCLUSIONS}

Consumers are more aware of ethical issues, but they are struggling to translate this into purchases, and not always rewarding these kinds of goods (Young et al., 2010; Carrington et al., 2010; Uusitalo \& Oksanen, 2004). Nevertheless punishment seems to be stronger than rewards, as rewarding good corporate behavior is usually more expensive than punishing bad behavior (Moosmayer, 2012; Clark et al., 2017) and the negative effects of unethical behavior have a substantially greater impact on WTPthan the positive effects of ethical behavior (Trudel \& Cotte, 2009).

In the managerial point of view, there is an interesting conflict: punishment versus reward. Information about companies' involvement with corruption is a relevant variable to consider and decide to buy a product. That is to say companies incur in great risk if they try to obtain illicit advantages. Even if, for a moment, we do not consider the ethical and legal issues, and think over the economic issue: do advantages gained in the short term compensate the losses in the long term? If managers are evaluated only in short terms salaries and bonuses - they would have individual motivations to develop activities that produce positive results in that scenario. However this behavior can compromise long term results by creating undesirable associations for the brand that may affect its value and, consequently, its market price. 
In the other hand, our data show that ethical behavior is not rewarded in the buying decision process. One reason could be that consumers expect that other people and large companies have an ethically behavior. In other words, for these consumers ethical behavior is not a quality, it is a common feature that companies have to adopt naturally. That means it is a waste of time, effort and money to try to communicate and get visibility to behaviors considered as minimum expected by consumers, as they do not value this attribute and will not pay more for it.

These results, combined, suggest that companies should behave ethically, if not by the reward they could get for it, at least for the punishment consumers are willing to give them. Firms should behave in a socially responsible manner, as consumers are even more punishing unethical companies.

Although some studies show that consumers are willing to pay more for ethical products and substantially less for unethical products (Trudel \& Cotte, 2009; Ferreira \& Ribeiro, 2016), our findings show that price promotion does not affect WTP. However, it should be pointed that our experiments only considered two different situations: no discount on price and 20\% discount. Future studies considering more aggressive discount may unfold different results. Furthermore, the product choice (best smartphone brand in the market) is a severe limitation and a possible bias of this study, as consumers can associate this with Apple or Samsung. For that, we suggest future studies use different products, less biased, to compare results.

Finally, it is important to point out that this study was conducted in only one country and with a specific product (smartphones). Future studies could explore if these findings are confirmed in situations with a different buying approach: higher versus lower involvement and perceived risk products, and/or hedonic versus utilitarian products.

\section{REFERENCES}

Andorfer, V. A., Liebe, U. (2015). Do information, price, or morals influence ethical consumption? A natural field experiment and customer survey on the purchase of
Fair Trade coffee. Social Science Research, 52, 330-350.

Carey, L., Shaw, D., \& Shiu, E. (2008). The impact of ethical concerns on family consumer decision-making. International Journal of Consumer Studies, 32(5), 553-560.

Carrington, M. J., Neville, B. A., \& Whitwell, G. J. (2010). Why ethical consumers don't walk their talk: Towards a framework for understanding the gap between the ethical purchase intentions and actual buying behaviour of ethically minded consumers. Journal of Business Ethics, 97(1), 139-158.

Carroll, A. B. (1999). Corporate social responsibility evolution of a definitional construct. Business \& Society, 38(3), 268295.

Cheit, E. F. (1964). Why managers cultivate social responsibility. California Management Review, 7(1), 3-22.

Clark, B., Stewart, G. B., Panzone, L. A., Kyriazakis, I. \& Frewer, L. J. (2017). Citizens, consumers and farm animal welfare: A meta-analysis of willingnessto-pay studies. Food Policy, 68, 112-127.

Ferreira, A. I. \& Ribeiro, I. (2016). Are you willing to pay the price? The impact of corporate social (ir)responsibility on consumer behavior towards national and foreign brands. Journal of Consumer Behavior, 16, 63-71.

Fishbein, M., \& Ajzen, I. (1977). Belief, attitude, intention, and behavior: An introduction to theory and research. Reading, MA: Addison-Wesley.

Gleim, M. R., Smith, J. S., Andrews, D., \& Cronin, J. J. (2013). Against the green: a multimethod examination of the barriers to green consumption. Journal of Retailing, 89(1), 44-61.

Hair, J. F. (2009). Multivariate data analysis. NJ: Pearson Prentice.

Herrmann, R. O. (1970). Consumerism: Its goals, organizations and future. The Journal of Marketing, 55-60.

Jägel, T., Keeling, K., Reppel, A., \& Gruber, T. (2012). Individual values and motivational complexities in ethical clothing consumption: A means-end approach.Journal of Marketing Management, 28(3-4), 373-396. 
Miller, K. E., \& Sturdivant, F. D. (1977). Consumer responses to socially questionable corporate behavior: An empirical test.Journal of Consumer Research, 4(1), 1-7.

Moosmayer, D. C. (2012). Negativity bias in consumer price response to ethical information. Business Ethics: a European Review, 21(2), 198-208.

Mulhern, F. J., \& Padgett, D. T. (1995). The relationship between retail price promotions and regular price purchases. The Journal of Marketing, 8390.

Palihawadana, D., Oghazi, P., Liu, Y. (2016). Effects of ethical ideologies and perceptions of CSR onconsumer behavior. Journal of Business Research, 69, 49644969.

Papaoikonomou, E. (2013). Sustainable lifestyles in an urban context: towards a holistic understanding of ethical consumer behaviours. Empirical evidence from Catalonia, Spain. International Journal of Consumer Studies, 37(2), 181188.

Tabachnick, B. G., \& Fidell, L. S. (2007). Experimental designs using ANOVA. Thomson.
Trudel, R., \& Cotte, J. (2009). Does it pay to be good? MIT Sloan Management Review, 50(2), 61.

Uusitalo, O., \& Oksanen, R. (2004). Ethical consumerism: a view from Finland. International journal of consumer studies, 28(3), 214-221.

Van Heerde, H. J. (2005). The proper interpretation of sales promotion effects: supplement elasticities with absolute sales effects. Applied Stochastic Models in Business and Industry, 21(4-5), 397-402.

Wheale, P., \& Hinton, D. (2007). Ethical consumers in search of markets. Business Strategy and the Environment, 16(4), 302315.

White, K., MacDonnell, R., \& Ellard, J. H. (2012). Belief in a just world: Consumer intentions and behaviors toward ethical products.Journal of Marketing, 76(1), 103-118.

Young, W., Hwang, K., McDonald, S., \& Oates, C. J. (2010). Sustainable consumption: green consumer behaviour when purchasing products. Sustainable Development, 18(1), 20-31. 